\title{
ARE MUSLIMS THE NEW CATHOLICS? EUROPE'S HEADSCARF LAWS IN COMPARATIVE HISTORICAL PERSPECTIVE
}

\author{
ROBERT A. KAHN ${ }^{*}$ \\ INTRODUCTION
}

A popular movement is sweeping across Europe aimed at restricting the public expression of European Muslim identity. ${ }^{1}$ Perhaps the best known example is the 2004 French law banning students, parents, and teachers from wearing hijabs (and other "ostentatious" religious symbols) in public schools. ${ }^{2}$ Meanwhile, several German states have made it illegal for school teachers to wear headscarves, and the city of Maaseik in Belgium banned the wearing of the burqa. ${ }^{3}$ In 2010 the French passed a ban on full-face veils, ${ }^{4}$ while laws targeting the burqa are under consideration in Belgium, Quebec, and the canton of Aargau in Switzerland. ${ }^{5}$

\footnotetext{
* Associate Professor University of St. Thomas School of Law. BA Columbia University, JD New York University School of Law, PhD Johns Hopkins University (Political Science). The author wishes to thank Jacqueline Baronian, Douglas Dow, Mitchell Gordon, Tom Berg and David Patton. An earlier version of this paper was presented at the June 2008 joint meeting of the Canadian Law and Society and United States Law and Society Associations held in Montreal, Canada.

1. According to a Pew Research Poll in April and May 2010, bans on facial veils are supported by large majorities of British, French and German voters. See Steven Erlanger, Parliament Moves France Closer to a Ban on Facial Veils, N. Y. TIMES, Jul. 13, 2010, http://www.nytimes.com/2010/ 07/14/world/europe/14burqa.html.

2. For an excellent overview of the debates over the passage of the French headscarf law, see John R. Bowen, Why The French Don't Like Headscarves: Islam, the State and Public SPACE (2006).

3. As of 2006 eight German states placed at least some restrictions on the wearing of the headscarf by public officials-including Bavaria and Baden-Württemberg, the two major Catholic states in Germany. See Länderscahe: Der ewige Streit um das Kopftuch, ZEIT ONLINE, Oct. 31, 2006. In 2006 a Belgian court upheld a burqa ban enforced by the city of Masseik. Burqa ban in Belgium upheld, ISLAM IN EUROPE (Jun. 15, 2006), http://islamineurope.blogspot.com/2006/06/burka-ban-in-belgiumupheld.html. Around the same time the Dutch proposed and then backed off from a broad ban on the burqa before settling on a narrower French-style ban on the wearing of burqas in public schools. See Dutch government proposes a ban on wearing burqas in public, USA TODAY, Nov. 17, 2006, http://www.usatoday.com/news/world/2006-11-17-dutch-burqas_x.htm?csp=34 The Netherlands: Government Said to Back Off Burqa Ban, N. Y. TIMES, Jan. 24, 2008, http:/www.nytimes.com/2008/ 01/24/world/europe/24briefs-burqa.html; Burqa ban extended to universities, DuTCH NEws, Nov. 26, 2008, http://www.dutchnews.nl/news/archives/2008/11/burqa_ban_extended_to_universi.php.

4. The law bans garments "designed to hide the face" in a wide variety of "public" places, including streets, markets, private businesses and public transportation. French 'Burqa' Ban Passes
} 
Nor is the anti-Muslim sentiment limited to clothing. In 2006 Denmark enacted citizenship examinations and mandatory declarations to make sure prospective immigrants have appropriate values. ${ }^{6}$ Under the law prospective immigrants must declare that they "understand and accept" that "men and women have equal rights and obligations," while agreeing that female circumcision and "the use of force to contract marriage" is illegal in Denmark. $^{7}$

The construction of Muslim religious buildings has also come under fire. In 2009 Switzerland passed a referendum banning the construction of minarets. ${ }^{8}$ Polling data shows that large percentages of the population of several European countries either supported the Swiss ban or proposed similar bans in their own countries. ${ }^{9}$

Finally, the Danish newspaper, Jyllands Posten, published twelve cartoons depicting the Prophet Mohammed (including one showing a bomb in his turban). ${ }^{10}$ The cartoons, which many Muslims found offensive, ${ }^{11}$ came on the heels of provocative anti-Muslim statements from leading figures in Danish public life, such as culture minister Brian Mikkelsen who

Last Legal Hurdle, FRANCE24, Oct. 7, 2010, http:/www.france24.com/en/20101007-french-burqa-banpasses-last-legal-hurdle-constitutional-council-veil.

5. See Belgium's Burqa Ban: Divided Country Finds Consensus on Islamic Veils, SPIEGEL ONLINE, Apr. 30, 2010, http://www.spiegel.de/international/europe/0,1518,692212,00.html (describing the burqa ban as the only issue of the Flemish and Walloon linguistic groups in the country agree on); Michèle Laird, Burqa Ban Debate Enflames Switzerland, SwISSTER, May 17, 2010 (describing a proposed ban in Aargau); Marion Scott, Most Canadians agree with Quebec's ban on burqa, Montreal GAZETTE, Mar. 27,2010 (describing Quebec's proposed burqa ban). On the other hand, a proposal for a ban on veils was recently rejected by the Premier of New South Wales, Australia. NSW Premier Rejects Burqa Ban Bill, SYDNEY MORNING HeRALD, June 23, 2010, http://news.smh.com.au/ breaking-news-national/nsw-premier-rejects-burqa-ban-bill-20100623-yw1t.html.

6. See Sine Lex et al., European Univ. Inst., Public and Political debates on Multicultural CRises in DenMark, 6 (2007); see also AmikAm NACHMANi, Europe AND its MusLim MinORITIES: ASPECTS OF CONFLICT, ATTEMPTS AT ACCORD, 140 (2009) (describing Germany's citizenship test, which includes a question about freedom of expression).

7. Id.

8. Swiss Voters Back Ban on Minarets, BBC News, Nov. 29, 2009, http://news.bbc.co.uk/ 2/hi/8385069.stm.

9. See Inst. of RACE Relations, The Swiss ReFEREndum on Minarets: BACKGROUND AND AFTERMATH 6 (2010) (explaining that according to the briefing paper, 41\% of French were opposed to the construction of new minarets and $59.3 \%$ of Belgians supported a ban on minaret construction).

10. For more on the cartoon controversy, see Robert A. Kahn, Flemming Rose, The Danish Cartoon Controversy, and the New European Freedom of Speech, 40 CAL. W. INT'L. L.J. 253 (2010).

11. For an overview of Muslim objections to the cartoons, see Rachel Saloom, You Dropped a Bomb on Me, Denmark-A Legal Examination of the Cartoon Controversy and Responses as It Relates to the Prophet Muhammad and Islamic Law, 8 RUTGERS J.L. \& RELIGION 1 (2006). 
spoke of a "cultural battle" against Muslim immigrants who refused "to accept Danish culture and European values." 12

According to Flemming Rose, then-editor of the Jyllands Posten's culture page, the cartoons were a necessary step to stand up to the totalitarian threat of self-censorship posed by radical Muslims and also a way of introducing Muslims to the Danish "tradition" of satire. ${ }^{13}$ Although this language did not directly single out Muslims as such, in defending the cartoons Rose also spoke of high Muslim birth rates, compared Muslims unfavorably to Latinos in the United States, and accused radical Muslim leaders of engaging in a cult of"victimology" that ignored the "relatively high crime rates" among immigrant groups.

Supporters of anti-Muslim laws and policies often portray them as a necessary defense against an Islamic threat, a threat drawn from a post1945 Cold War perspective. ${ }^{15}$ Muslim religious leaders are branded as "fascists" and the Muslim headscarf becomes a symbol of totalitarianism; those who oppose publishing the Mohammed cartoons are decried as "appeasers." 16 On one level, this framing makes sense since it reflects the historical experience of Europeans over the last hundred years. But it also has its problems. For one thing, the demands made by Muslims are religious as well as political. Furthermore, equating Islam with Europe's greatest inner demons overstates whatever challenges Muslims may pose to European liberalism while making compromise less likely. ${ }^{17}$

12. See Bent Nørby Bonde, How 12 Cartoons of the Prophet Mohammed Were Brought to Trigger an International Conflict, 28 NORDICOM REV. 33, 36 (2007) (reprinting Mikkelsen's comments); see also Robert A. Kahn, The Danish Cartoon Controversy and the Exclusivist Turn in European Civic Nationalism, 8 STUDIES IN ETHNiCITY AND NATIONALISM 524, 528 (2008) (citing the harsher comments of Pia Kjærsgaard, leader of the far right Danish People's Party, who rejected the "clash of cultures" framework by asserting "there is only one civilisation and it is ours.").

13. Flemming Rose, Why I Published Those Cartoons, WASH. Post, Feb. 19, 2006, http://www.washingtonpost.com/wp-dyn/content/article/2006/02/17/AR2006021702499.html.

14. Id.; Flemming Rose, Why I Published the Muhammad Cartoons, SPIEGEL OnLINE, May 31, 2006, http://www.spiegel.de/international/spiegel/0,1518,418930,00.html.

15. Robert A. Kahn, The Headscarf as a Threat: A Comparison of U.S. and German Legal Discourses, 40 VAND. J. TRANSNAT'L L. 417 (2007).

16. For more on how totalitarian imagery plays into debates about Islam in Europe, see Kahn, supra note 10.

17. When, however, Muslims turn the analogy around and present themselves as victims of Nazi style polices, there are often sharp complaints. For example, consider Fereshta Ludin, the Afghani-born schoolteacher whose refusal to take off her headscarf led to a landmark headscarf case in Germany. She compared her situation to that of Jews "just before the Holocaust." Kahn, supra note 15, at 433 n.132. In response, local Christian Democrat politicians wanted to prosecute her for Holocaust denial. Id. For more background on the argument that Muslims are going to be the next victims of the Holocaust, see NACHMANI, supra note 7, at 132-40. Interestingly, the German citizenship test contains no questions about the Holocaust. Id. at 140 . 
This Article proposes an alternate frame. What if Muslims-rather than being Soviets or Nazis-in-training - are the new Catholics? During the second half of the nineteenth century, a struggle erupted between Catholics and liberals over schools, civil marriage, and burial ${ }^{18}$ - the same issues at the center of the current debates in Europe. The key event of this struggle was the German Kulturkampf (1871-1887), during which Otto von Bismarck, at the head of a coalition of German liberals and nationalists, led a campaign to separate German Catholics from the "reactionary" influences of the Papacy. The means for doing so included restrictions on religious speech, banning Jesuits, state assumption of civil marriage, and requiring new priests to swear an oath of loyalty to the German state. ${ }^{19}$ Across the Atlantic, state governments in the United States were busy passing laws banning public school teachers from wearing clerical garb. ${ }^{20}$

Looking at current European developments through the lens of Kulturkampf has several advantages. ${ }^{21}$ First, it reinforces the idea that Islam-like Catholicism - is a religion, rather than simply a political ideology. Although there is a downside to viewing Islam - or any other faith - as devoid of politics, ${ }^{22}$ the focus on "political Islam" obscures the complex reasons Muslims engage in religious practices. A more religiously sensitive approach will help explain why bans on wearing headscarves is more complicated than simply banning Islamist ideology.

18. For a brief overview, see CHRISTOPHER CLARK \& WOLFRAM KAISER, The European Culture Wars, in Culture Wars: Secular-Catholic Conflict in Nineteenth Century Europe 1 (Christopher Clark \& Wolfram Kaiser eds., 2003).

19. Ronald J. Ross, The Failure of BismarcK's KulturkampF: CATHOlicism and State POWER IN IMPERIAL GERMANY 4-7 (1997).

20. Virgil C. Blum, Religious Liberty and the Religious Garb, 22 U. CHIC. L. REV. 875 (1955).

21. I am not the only one making this comparison. In a recent blog entry, Ates Altinordu links the anti-Catholic stereotypes of the Kulturkampf to the current stereotypes directed at Muslims. He concludes that European Muslims must work hard to make sure they do not become "the Catholics of tomorrow." Ates Altinordu, Varieties of Anti-Religious Imagination, THE IMMANENT FrAME: SECUlARISM, REligion, AND THE PUBlic SPHERE (Apr. 30, 2008), http://blogs.ssrc.org/tif/2008/ 04/30/varieties-of-anti-religious-imagination/. For a similar claim about anti-Catholic and anti-Muslim discourse from the perspective of the literature on democratization, see José Casanova, Catholic and Muslim Politics in Comparative Perspective, 1 TAIWAN JOURNAL OF DEMOCRACY 89, 89 (2005) (noting similarities between "the old discourse on Catholicism that prevailed in Anglo-Protestant societies" and "[t]he contemporary global discourse on Islam as a fundamentalist, antimodern and undemocratic religion.").

22. To call radical Islam "fundamentalist"-just like labeling ultramontane Catholicism "reactionary" - undermines the modernist elements in both movements. This modernism is most apparent in the way both movements brought new voices into the political system. For an interesting series of essays making this point in the Islamic context, see MODERNIZING ISLAM: RELIGION AND THE PuBliC SPHERE IN EUROPE AND THE MiddLE EAST (John L. Esposito and François Burgat eds., 2003). 
Second, focusing on European and U.S. anti-Catholicism raises the possibility that anti-Muslim policies are not just about defending Karl Popper's "the open society" against political extremists. ${ }^{23}$ Just as nineteenth century German liberals worried about the specifically religious content of Catholicism, high Catholic birth rates and Catholic cultural practices that differed from those favored by Protestants, ${ }^{24}$ current anti-Muslim sentiment in Europe turns on more than a fear of Muslim radicals. ${ }^{25}$

Finally, to strike a prescriptive note, the anti-Catholic laws ultimately failed. For one thing, the laws often did not achieve their stated goals. ${ }^{26}$ Bismarck's laws failed to separate German Catholics from a "reactionary" Rome, while in the United States the clerical garb laws did not prevent Catholics from teaching in public schools. Nor did the anti-Catholic laws and policies succeed in isolating Catholics from the rest of society. Herein lies a hope for the future-if the United States and Germany could come to terms with Catholicism in the nineteenth and twentieth centuries, the same ought to be true of Europeans learning how to live with Muslims today.

The remainder of this Article explores the Catholic-Muslim comparison in greater depth. Part I looks at how supporters of the Kulturkampf and clerical garb laws in the United States viewed the "threat" posed by Catholics. Part II turns to contemporary Europe and argues that many of the arguments used in today's debates over Islam are similar to the anti-Catholic discourse of the Kulturkampf. Part III switches focus to how the law operates in practice and recounts the practical difficulties that arose when the Kulturkampf and bans on clerical garb were enforced. Part IV uses these practical difficulties of past clothing bans to pose a series of speculative conclusions about current European bans on the headscarf and burqa. Finally, the Article closes on a hopeful note: the successful integration of Catholics in present day Germany and the United States today suggests that the fears behind the anti-Muslim laws and policies are overstated.

23. In his Washington Post op-ed piece defending his decision to publish the cartoons, Flemming Rose invoked Karl Popper's THE OPEN SOCIETY AND ITS ENEMIES (1945) - a classic text of Cold War liberalism - to highlight the importance of not tolerating the intolerant. Rose, supra note 13.

24. For more, see infra notes 43-54 and accompanying text.

25. For more, see infra notes 78-91 and accompanying text.

26. This is the main thesis of Ross's book. See Ross, supra note 19, at 12-14 (arguing that the Kulturkampf demonstrates the limits of the power of the German state and national liberals to make policy). 


\section{THE KULTURKAMPF, CLERICAL GARB LAWS, AND ANTI- CATHOLIC STEREOTYPES}

In discussing conflicts over Islam, writers sometimes use the term Kulturkampf, literally translated as "struggle between cultures." ${ }^{27}$ The reference is to Samuel Huntington, who argued that the current world is divided into discrete cultures and that the current age dominated by a "clash of civilizations." ${ }^{28}$ The term Kulturkampf, however, also has a narrower, historical meaning. It refers to an event that occurred within Europe- the struggle between "modern" liberals and a resurgent Catholic church during the nineteenth century. It is this narrower use of Kulturkampf that this Article seeks to explore.

The nineteenth century conflicts between Catholics and liberals took place in various countries. ${ }^{29}$ However, the greatest conflict occurred in Germany, where Chancellor Otto von Bismarck, at the head of a coalition of nationalists and liberals, enacted a series of laws designed to separate German Catholics from the Pope. ${ }^{30}$ The arrests, prison sentences, and expulsions ruined lives of individual Catholics without ultimately advancing Bismarck's long-term goal of reducing Catholic influence in German social and political life. ${ }^{31}$ Small wonder other European liberals saw the Kulturkampf as an example of what to avoid. ${ }^{32}$

To understand why the Kulturkampf came about despite its unpopularity, some historical background is necessary. During most of the eighteenth and nineteenth centuries, the area currently known as Germany was made up of a loose confederation of small states, a few larger ones such as Bavaria, and Prussia, which by the mid-eighteenth century was

27. Timothy Garton Ash, Sarkozy Is Half Right: All Europeans Must Understand the Swiss Mistake, THE GuARDiAn, Dec. 10, 2009 at 33 (criticizing the Swiss Minaret Ban, Garton Ash spoke of "the danger of sliding into a culture war, a Kulturkampf").

28. Samuel P. Huntington, The Clash of Civilizations?, 72 ForeIGN AFF. 22 (1993). The use of the term Kulturkampf is not limited to Germans. For example, William Rees-Mogg, calling for new antiterrorism policies referred to the struggle against terrorism as "a Kulturkampf in Bismarck's terms" William Rees-Mogg, This Time We Were Lucky, This Time..., THE TIMEs (London), July, 2, 2007, http://www.timesonline.co.uk/tol/comment/columnists/william_rees_mogg/article1886870.ece.

29. See CLARK \& KAISER, supra note 18, at 1-2 (noting that during the last quarter of the nineteenth century there were major conflicts between Catholics and secular liberals in France, Belgium and Switzerland).

30. Ross, supra note 19 , at 4-8.

31. Id. at 7 (noting that Catholic civil servants were demoted or lost their jobs and rank and file Catholics found it hard to find priests to administer the sacraments" and that by 1880 "more than half of Prussia's Catholic episcopate was in exile or prison, nearly a quarter of all parish priests were without pastors, and a third or more of all religious houses and congregations had been suppressed").

32. CLARK \& KAISER, supra note 18 , at 4. 
already a major European power. ${ }^{33}$ To the southeast stood the Habsburg Empire, a Catholic state that occupied many territories including presentday Austria and the Czech Republic, both of which had large German speaking populations. ${ }^{34}$ As the idea of nationalism spread across Europe in the nineteenth century, Germans debated between having a "large" Germany that would include the German lands of the Habsburg Empire and having a "small" Germany that would leave them out. ${ }^{35}$ In the $1860 \mathrm{~s}$, matters came to a head and by 1871 a new German Empire had arisenone that excluded the Habsburg lands and was dominated by Prussia. ${ }^{36}$

The unification process saw the new German state fight wars with Austria (1866) and France (1870-71) — both Catholic powers. By 1871, Catholics made up thirty-six percent of the German population. ${ }^{37}$ Moreover, although its supporters believed they were fighting against "reactionary" Catholicism, the Kulturkampf itself was a reaction to a reinvigorated Catholic church. The mid-nineteenth century saw a considerable popular mobilization of Catholicism, including membership increases in Catholic institutions, as well as a new popular piety involving relics, plaster saints, and public rituals that made Protestants and some middle-class Catholics uncomfortable. ${ }^{38}$

At the same time, Catholics were able to use the new democratic institutions established in the wake of the liberal revolution of 1848 that swept across the German states to gain a measure of political power. ${ }^{39}$ In

33. Until 1806 this confederation took the form of the Holy Roman Empire, nominally governed by a Habsburg prince who was also the Emperor of Austria and always a Catholic. E.J. PASSANT, A SHORT HISTORY OF GERMANY 1-2 (1969). After the defeat of Napoleon in 1815, this took the form of the German Confederation. Id. at 15-18. While dominated by Austria in its early years, the Confederation was no longer an explicitly Catholic body. Id. at 19-21 (describing 1815-58 as a period of Austrian dominance over the German Confederation). Meanwhile, Prussia-while religiously diverse - saw its mission as protecting the rights of Calvinists in the Holy Roman Empire. Id. at 3; see also MARY FulbroOK, A CONCISE History OF GERMANY 76 (1990) (describing Prussia as a "composite" state made up of Catholics and Lutherans as well as Calvinists).

34. PASSANT, supra note 33, at 8-9 (noting that the Habsburg Empire also included a large number of non-German minorities which weakened its claim to speak as a defender of German power).

35. Walter Schmidt, The Nation in German History, in THE NATIONAL QUESTION IN EUROPE IN HistORICAL CONTEXT 148, 161-62 (Mikuláš Teich and Ray Porter eds., 1993); see also ALAN WAtson, The Germans: Who They ARE Now 32 (rev. ed. 1994) (describing Berlin and Vienna's competing plans for German reunification).

36. For an overview, see FULBROOK, supra note 33, at 125-31. The new German Empire was federal - the Emperor ruled over foreign and military affairs, while the individual states retained control over domestic issues. ARNOLD J. HEIDENHEIMER, THE GOVERnMENT OF GERMANY 9-11 (3d ed. 1970).

37. Marjule Anne Drury, Anti-Catholicism in Germany, Britain, and the United States: A Review and Critique of Recent Scholarship, 70 CHURCH HISTORY 98, 111 (2001).

38. CLARK \& KAISER, supra note 18 , at 3; Ross, supra note 19 , at 23 ; Drury, supra note 38 , at $111,117$.

39. Martin Spahn, Kulturkampf, in 8 The CATHOLIC ENCYClOPEDIA, 703, 704 (1910). 
1870 - the year before Bismarck began instituting anti-Catholic laws - the Catholic-based Center Party won a massive electoral victory in the Prussian parliament. ${ }^{40}$ Added to this was the new assertiveness of the Papacy-as seen in the Syllabus of Errors (1864), which indicted liberal society, and the Decree on Papal Infallibility (1870), which suggested that the ultimate authority for German Catholics lay not in Berlin, but in Rome. ${ }^{41}$

Although the renewed Catholic assertiveness of the mid-nineteenth century might have justified some response, German liberals exaggerated the threat and stereotyped Catholics in ways that followers of the current European debates over Islam will find familiar. First, German liberals cast the concern about Catholics in demographic terms. They worried, for example, about high Catholic birthrates and conversions through mixedmarriages. ${ }^{42}$ These concerns remained robust despite Prussian authorities acknowledging that the Catholic population was not increasing and, in fact, most of the offspring of Catholic-Protestant marriages were being raised as Protestants. ${ }^{43}$

Added to the demographic concerns were ethno-racial ones. Poles were almost entirely Catholic, and during this period, the German Empire included several provinces with large Polish minorities, including West Prussia and Silesia; in Posen, Poles made up $60 \%$ of the population. ${ }^{44}$ Concerns arose that German Poles would revolt, as they had in Russian Poland a few years earlier. ${ }^{45}$ Because the Poles were overwhelming Catholic, German nationalists viewed Catholicism with suspicion. For example, when a celebration of the Papal Jubilee in 1871 was held in the

40. The Center Party increased its representation in the Prussian Parliament from five percent to around twenty percent. See Margaret Lavinia Anderson, The Kulturkampf and the Course of German History, 19 CENT. EUR. HisT. 82, 88-89 (2008).

41. See Ross, supra note 19 , at 5 .

42. See id. at 5-7.

43. Id.

44. Shalom Reichman \& Shlomo Hasson, A Cross-cultural Diffusion of Colonization: From Posen to Palestine, 74 AnNALS OF THE Ass'N OF AM. GEOGRAPHERS 57, 58 (1984).

45. The rebellion took place in 1863. See Norman Davies, HeArt of Europe: A SHORT HistORY OF POLAND 166-68 (1985). Meanwhile, on the Russian side of the imperial frontier, Catholic Poles were subject to a Tsarist Russification campaign that, like its German counterpart, had a religious aspect to it. See Theodore R. Weeks, Russification: Word and Practice, 148 PROC. OF THE AM. PHIL. SOC'Y 471, 478-79 (2004) (describing how during the 1860s the Tsarist governor general of Russian Poland worried about the "polonizing" influence of Catholic and Uniate clergy). There are differences, however. The "modernization" theme-present in both the anti-Catholic and anti-Muslim discourses under discussion here-was not a major part of the Russian discourse about Catholics (although it was to a limited extent present in the discourse about Jews, who were seen as a having a medieval, Asian religion). Id. at 472. Instead, Catholics — while respected as having a high culture-were seen as getting in the way of a larger project of connecting people living in Lithuania and Poland with their true Russian identity. See id. 
Polish language, nationalists worried about "the Polish tendencies of the Catholic hierarchy." 46

A third set of arguments involved categorizing the Church as antimodern. One argument focused on the growth of popular rituals. As noted, these rituals-which historian Marjule Anne Drury ${ }^{47}$ refers to as "devotional kitsch"-made Protestants and middle-class Catholics uncomfortable. German middle-class culture shied away from the culture of display typical of ultramontane Catholics. ${ }^{48}$ This was especially true of liberal Protestants, who were moving in the direction of a more secular, cultural view of religion. ${ }^{49}$ So, while Protestants began to view Sunday as a day for Beethoven and museums, Catholics spent their leisure time on numerous feast days as well as on "drunken and riotous" trips to pilgrimage sites. $^{50}$

In addition, there was a broader complaint that Catholics were superstitious and believed in miracles. ${ }^{51}$ The presence of such "backward" views among a large segment of the population confounded the claim that Germany was a modern nation. Added to this were economic claimsclaims that Catholics were underrepresented in schools, had low incomes, worked in marginal areas of the economy, and were generally excluded from the elites of society. ${ }^{52}$ Though such arguments could lay the basis for egalitarian reform, the response in Germany of the 1870 s was to combat "Catholic backwardness, provincialism and cultural inferiority."

In this atmosphere, anti-Catholic horror stories flourished. Catholicism was associated with Jesuit conspiracies (including one supposedly responsible for the death of a lion at the Berlin zoo), wild stories of nuns and priests disregarding their vows of celibacy, and cruelty toward school children. ${ }^{54}$ These stories sometimes led to violence, as occurred during the

46. Ross, supra note 19 , at 22 . According to Ross, the Poles, "[1]ike the communists of a later era ... aroused the hostility and suspicion of the public . . . because of their alleged revolutionary potential, especially in the kingdom's Polish provinces." Id.

47. Drury, supra note 37 , at 111.

48. See id. at 116. Ultramontanism refers to the idea developed from medieval times that the ultimate authority in the Catholic Church rests not with a secular prince but-beyond the mountainswith the Pope. Umberto Benigni, Ultramontanism, 15 THE CATHOLIC ENCYCLOPEDIA 125 (1912).

49. See Drury, supra note 37 , at 117.

50. Id. at 118-19.

51. Ross, supra note 19 , at 18.

52. Id. at 23-24. The socio-economic claims of Kulturkampf supporters sparked a debate in the late nineteenth century and played a formative role in Max Weber's thought. For a summary of the debate, see Drury, supra note 37, at 121-31.

53. Ross, supra note 19, at 23.

54. Id. at 18-20. 
1869 Moabit riots, in which a mob of thousands attacked a Dominican chapel in Berlin after the priest was accused of sexual misconduct. ${ }^{55}$ AntiCatholic sentiment also found expression in the cartoons of Wilhelm Busch, whose book-length comic strip, Pater Filucius, satirized an avaricious Jesuit. ${ }^{56}$ Withheld for two years by German authorities because of fears it might offend Catholics, Pater Filucius was a best seller on its release in $1872 .^{57}$

A final strand of support for the Kulturkampf came from those who saw Catholics as agents of the Pope. In explaining this aspect of antiCatholic thought, the Catholic Encyclopedia partly blamed Bismarck's jealousy - for at the very moment Bismarck's Prussia succeeded in "restor[ing] to Germany its former imperial grandeur," Rome declared the infallibility of the Pope.$^{58}$ But other liberals shared Bismarck's concerns, including historian Hans Delbrück who in 1897-a full decade after the end of the Kulturkampf - could still say that the threat "social democracy" posed to the German Empire paled before that posed by ultramontane Catholicism. ${ }^{59}$ Inspired by fears that the Pope would use the infallibility decree to restore the Papacy's worldly powers, ${ }^{60}$ German liberals saw the Kulturkampf as part of a larger power struggle between the Papacy and the Holy Roman Empire. ${ }^{61}$ In this struggle, German Catholics were either pawns who were encouraged to break from the ultramontane policies of Pius IX or a "foreign element" in the German body politic. ${ }^{62}$

The same forces that inspired the Kulturkampf were also present in the United States, a country that, like Germany, combined Protestant

55. Id. at 26 .

56. For more, see Françoise Forster-Hahn, A Hero for All Seasons? Illustrations for Goethe's "Faust" and the Course of Modern German History, 53 ZEITSCHRIFT FÜR KUNSTGESCHICHTE 511, 519 (1990). However, Busch is much better known as the author of Max and Moritz, a pioneering work in the world of comics.

57. Richard H. Schaefer, Kulturkampf Then: Ludwig Windthorst vs. Bismarck, 1996 FIDELITY MAGAZINE 36, 38.

58. Spahn, supra note 39, at 706.

59. Quoted in Drury, supra note 37, at 114.

60. Id.

61. In his March 10, 1873 speech to the German House of Lords, Bismarck argued that the struggle with the Catholic Church was not "confessional," but "political." As such, it was part of "the age-old struggle between kingship and priesthood" one that "shaped the German history in the Middle Ages ... in the form of the conflict between emperors and popes." Otto von Bismarck, Speech to the Prussian House of Lords (1873), http://www.zum.de./psm/imperialismus/bismarck3e.php (last visited Mar. 18, 2011). Bismarck made the same point the previous year when he announced to the Reichstag that "we shall not go to Canossa" -a reference to German Emperor Henry IV, who in 1077 went to the Italian town and stood for three days bareheaded in the snow to submit to Papal authority. See Ross, supra note 20 , at 24-25.

62. See Drury, supra note 37 , at 113. 
dominance with a large Catholic minority. ${ }^{63}$ While organized antiCatholicism was present in American public life from the arrival of German and Irish Catholics in the 1830s until well into the twentieth century, ${ }^{64}$ the passage of clerical garb laws in the late nineteenth century casts an interesting light on the current debate over Muslim teachers wearing headscarves.

As in Germany, part of the pressure for anti-Catholic laws in the United States arose at least in part from partisan causes-in this case conflicts between the Democratic and Republican parties. ${ }^{65}$ For example, in the mid-1870s a debate arose over the Blaine Amendment, which, had it passed, would have amended the Religion Clause of the First Amendment to ban public support for parochial education. ${ }^{66}$ The amendment was the creature of James Blaine, who sought the Republican nomination for President in 1876 and who believed that taking a stand against "sectarian" (i.e., Catholic) education would cement a relationship between Protestantism and the Republican Party. ${ }^{67}$ This was not an isolated example; then Ohio Governor Rutherford B. Hayes won re-election in 1874 by linking the Democrats to Catholic plotters. ${ }^{68}$ In the 1876 election the Republicans tried to tar the Democrat nominee, New York Governor Samuel Tilden, as too closely linked with the New York Catholic hierarchy. ${ }^{69}$ Further, Rhode Island considered legislation that would make it illegal to "dissuade" a parent from sending children to a public school. ${ }^{70}$

While the Blaine Amendment ultimately failed, ${ }^{71}$ several states, including New York, Pennsylvania, Missouri, and Indiana, passed laws

63. For a discussion of the position of Protestantism in the United States during the nineteenth century, see Robert T. Handy, The Protestant Quest for a Christian America, 22 CHURCH Hist. 8 (1953). Meanwhile, as in Germany, Protestant dominance was accompanied by demographic growth of Catholics - the percentage of Catholics in the United States grew from five percent in 1850 to seventeen percent by 1906. Julie Byrne, Roman Catholics and Immigration in Nineteenth Century America, NAT'L HUMANITIES CENTER, http://nationalhumanitiescenter.org/tserve/nineteen/nkeyinfo/nromcath .htm (last updated Nov., 2000).

64. For a classic overview of the structures of White Anglo-Saxon Protestant dominance in the United States during the late nineteenth and early twentieth-centuries, see E. DigBY BALtZELL, THE Protestant Establishment: ARISTOCRACY \& CASTE IN AMERICA (1964).

65. Steven K. Green, The Blaine Amendment Reconsidered, 36 AM. J. LEGAL HiST. 38 (1992).

66. Id.

67. Id. at 54 .

68. Id. at 49 .

69. Id. at 57

70. Id. at 55 .

71. Once Blaine lost the battle for the 1876 Republican Presidential nomination to Hayes, his interest in the school funding issue waned and the bill failed in the Senate by four votes. Id. at 67 . 
making it illegal for teachers to wear clerical clothing while at school. ${ }^{72}$ Supporters of these laws argued that by taking an oath of poverty, nuns, a major target of the clerical garb laws, lacked the moral independence necessary to teach children. ${ }^{73}$ Debates arose over whether nuns wore their clothing as a matter of choice ${ }^{74}$ and whether a ban on the nun's habit was necessary to preserve the state. ${ }^{75}$ The message conveyed by the wearer of clerical clothing also aroused suspicion: was it a factual statement that the wearer was Catholic, or part of a scheme for teaching Catholic beliefs? ${ }^{76}$ Taken as a whole, the debate over clerical garb laws revealed a discomfort with religious difference that was shared by both by Kulturkampf proponents and many European liberal and secularist opponents of the hijab and burqa.

\section{RETURN OF THE KULTURKAMPF? LIBERAL FEARS OF ISLAM}

Although supporters of the Kulturkampf and clerical garb laws made their points decades before anyone took much notice of European Muslims, their arguments parallel those made by opponents of the hijab and burqa. This similarity suggests that the Muslim "threat" facing Europe is far from unique and that the best parallel to the current debate over the Muslim headscarf is not the failure of European democracies to fight totalitarians in the years before and after World War II, but rather Europe's long history of intolerance toward outsiders, including-for Protestant Europe of the 1870s - Catholics. The following outlines the key similarities between the anti-Catholic prejudices of the Kulturkampf and the anti-Muslim biases that inform today's debate.

Before doing this, however, it is necessary to briefly describe the rise of anti-Muslim sentiment in Europe. Although the encounter between Muslims and the West goes back for centuries, ${ }^{77}$ Muslims first came to Europe in large numbers in the years after 1945 as the continent sought to rebuild itself after the devastation of World War II. ${ }^{78}$ At this time, migration was not seen as problematic - in part because of the expectation

72. Blum, supra note 20 , at $875-76$.

73. See id. at 877 .

74. Id. at 879 .

75. Id. at 881 .

76. See id. at $884-86$

77. For a brief overview of relations between Muslims and the West before 1945, see Jane L. Smith, Introduction, in Yvonne Yazbeck Haddad ed. MuSLIMS IN THE WeST: From SoJOURNERS TO CiTizENS 3-4 (2002).

78. Id. at 4 . 
that the migrants, mostly male guest workers, would return home. ${ }^{79}$ According to Islamic studies expert Jane L. Smith, during this period "Islam was seen as a kind of transient 'cultural baggage."' 80

During the 1980s this model began to change. On the one hand, European countries began to encourage family reunification and a new group of Muslim asylum seekers fled to Europe. ${ }^{81}$ This coincided with the emergence of a generation of European born Muslims - the sons and daughters of the guest workers, many of who were frustrated by the treatment experienced by their parents. ${ }^{82}$ At the same time, the oil crises of the 1970s spread waves of unemployment across over Europe, which led to the accusation that "Arabs" were stealing European jobs. ${ }^{83}$

Initially the conflict between Muslim migrants and "natives" focused on xenophobia, rather than concerns with the specifically Islamic nature of Muslim migrants. When, for example, in the early 1990s four right-wing extremists set fire to the house of a large Turkish family in Solingen, Germany killing five people, thousands of citizens gathered to honor the memory of the victims. ${ }^{84}$ The town's mayor spoke out against "hatred of foreigners" and for "a democratic, fair and tolerant Germany." 85 The religious identity of the victims - clearly demonstrated by the fact that the coffins pointed toward Mecca ${ }^{86}$ _ did not appear significant of the time.

Slowly, concerns about culture and religion became more prominent. One reason was the emergence of a specifically Islamic ideology of antiWestern protest. ${ }^{87}$ At the same time, the emergence of European wide institutions triggered an identity crisis which, according to Raphaël Liogier, Sociology Professor at the Institute for Political Studies in Aix-enProvence, created a situation in which "Islam has become almost the only

79. Id.

80. Id.

81. Id.

82. Id. See also Raphaël Liogier, Islam: A Scapegoat for Europe's Decadence-How Muslims Have Been Taken Hostage by Europe's Most Acute Civilizational Crisis Since WWII, HARV. INT'L REV. (Jan. 6, 2011), http://hir.harvard.edu/islam-a-scapegoat-for-europe-s-decadence.

83. Liogier, supra note 82.

84. Stephen Kinzer, Thousands of Germans Rally for Slain Turks, N. Y. TIMES (June 3, 1993), http://query.nytimes.com/gst/fullpage.html?res=9F0CE0DE143DF937A35755C0A965958260.

85. Id.

86. Id.

87. Liogier, supra note 82 (describing how Islam, "besides being a religion, henceforth acted as a sort of anti-racist and anti-colonial banner"). 
Europe-wide negative element which European identities can define themselves against." ${ }^{88}$

This result was a new questioning of "whether Muslims can or are willing to be integrated into European society and its political values." ${ }^{89}$ The change took place quickly. In 1991 Fritz Bolkenstein, a liberal party leader in the Netherlands, triggered a scandal in his home country by suggesting the incompatibility of Muslim and Western values; by 2000 such views would be mainstream. ${ }^{90}$ To take another example, the headscarf issue first came to prominence in France in 1989, when three headscarf wearing girls were expelled from a public school. According to Liogier, the debate that followed "gripped" the country. ${ }^{91}$ By 2004 France banned all headscarves in public schools with a good deal of public support. ${ }^{92}$

It was against this background that European opponents of radical Islam began to speak of a "culture war." ${ }^{93}$ When they did so, they often fell back on many of the same categories used by Bismarck and his liberal supporters to describe Catholics. ${ }^{94}$ In a similar way, supporters of European headscarf laws raised many of the same concerns supporters of clerical garb laws raised about the nun's habit. ${ }^{95}$

Like their nineteenth century predecessors, supporters of the twentyfirst century "culture war" express alarm at the demographic "surge" of Muslims, which will allegedly result in the creation of "Eurabia." ${ }^{196}$ And, as in the Kulturkampf, Europe's "defenders" tend to overstate the number of European Muslims: although Muslims make up no more than ten percent of

88. Id. Liogier notes that France, "once a world intellectual powerhouse," now felt the "brunt" of becoming "a peripheral player at the fringes of the Anglosphere" while Europe felt that it no longer "count[ed] on the world stage." Id.

89. Tariq Modood, Muslims and European Multiculturalism, OPEN DEMOCRACY (May 14, 2003), http://www.opendemocracy.net/printpdf/1214.

90. Kahn, supra note 12 , at 530.

91. Liogier, supra note 82.While Jean Marie Le Pen, leader of the right-wing, anti-immigrant National Front supported the expulsions, so did a number of people on the Left. See JONATHAN Marcus, The National Front in French Politics: The Resistible Rise of Jean Marie Le Pen, 92-95 (1995).

92. Liogier, supra note 82 . A December 2003 poll found $72 \%$ of the French in support of the then proposed ban on headscarves in public schools. BowEN, supra note 2, at 124.

93. See supra note 12 and accompanying text.

94. See supra notes $42-62$ and accompanying text.

95. See supra notes 73-76 and accompanying text.

96. Daniel Pipes, Europe or Eurabia?, THE Australian, Apr. 15, 2008, www.danielpipes.org/article/5516. 
the population in any European country, opponents warn that one daysooner rather than later-Europe will have a majority Muslim population. ${ }^{97}$

Niall Ferguson, echoing similar fears about demographics, added that when he sees a minaret in Europe, it conjures up an image of "decline and fall." ${ }^{98}$ Of course, these concerns about demographics - even if true-only make sense if one assumes a fortiori that Muslim migrants are not Europeans (otherwise, why should an increase in Muslims suggest a decline?). This is similar to the view of German liberals who worried about Catholic birth rates. ${ }^{99}$

Nor is there any lack of ethno-racism among today's culture warriors. Just as Bismarck and his supporters worried about the "revolutionary" potential of the Poles, proponents of the headscarf laws worry about Muslims disrupting European society. ${ }^{100}$ Just as Bismarck and the German nationalists feared revolution and a Polish take-over, opponents of the hijab and burqa associate them with a rejection of assimilation. ${ }^{101}$ Liberal Dutch MP Geert Wilders explained the Dutch proposal to ban the burqa:

We don't want women to be ashamed to show who they are. Even if you have decided yourself to do that [wear a burqa] you should not do it in Holland, because we want you to be integrated, assimilated into Dutch society. If people cannot see who you are, or see one inch of your body or your face, I believe this is not the way to integrate into our society.

97. According to Pipes, because of low European and high Muslim birth rates, Amsterdam and Rotterdam will be Muslim majority cities by 2015, and by 2050 Russia could become the first Muslim majority European country. Id. For a discussion of how demographics plays into fears of a Muslim dominated Europe, see NACHMANI, supra note 6, at 130-32.

98. Niall Ferguson, Op-Ed., Eurabia?, N. Y. TIMES, Apr. 4, 2004, http://www.nytimes.com/2004/ 04/04/magazine/04WWLN.html.

99. See supra notes $42-43$ and accompanying text.

100. The clearest parallel is the equation of Islam with terrorist acts such as the subway bombings in Madrid and London. For example, writing on the fifth anniversary of the 7/7 subway bombing, Stuart Reid wrote in the Catholic Herald that "[w]ithout a strong Islamic element in our nation, there would have been no 7/7." Stuart Reid, The Lessons of 7/7: Islam, Tolerance and American Wars, CATHOLIC HERALD, Jul. 7, 2010, http://www.catholicherald.co.uk/commentandblogs/2010/07/07/the-lessons-of77-islam-tolerance-and-american-wars/. Reid then praised the French, Belgians and Swiss for "showing the way" by restricting minarets and burqas. $I d$.

101. This often is expressed in terms of fear that European Muslims will create parallel societies. See, e.g., Andrea Brandt and Cordula Meyer, A Parallel Muslim Universe, SpIEgEl OnLine, Feb. 20, 2007, http://www.spiegel.de/international/0,1518,467360,00.html (expressing fear that "Islamic associations are . . . accelerating the drift towards a parallel Muslim society").

102. See Mark Mardell, Dutch MPs to Decide on Burqa Ban, BBC News (Jan. 16, 2006), http://news.bbc.co.uk/2/hi/europe/4616664.stm (quoting Wilders). 
A dissenting judge in the 2003 Ludin case, in which the German Federal Constitutional Court invalidated a civil service ban on headscarves, made a similar point about the "German constitutional understanding" of women's clothing: "The free person shows their face."103

Fears of a Muslim "revolution" also appear in the debate over Geert Wilders's 2008 film Fitna, which equates Islam with terrorism and calls for the end of Muslim immigration. ${ }^{104}$ Some of this sentiment comes from Wilders himself who argues that Islam "seeks to destroy our Western Civilization," 105 in similar vein to the way the Kulturkampf's supporters feared Catholics. In the debate over the film, Wilders has also become a martyr along the lines of Theo van Gogh, who is viewed by many as a victim of a culture war directed by Islam against the West. ${ }^{106}$

Other concerns about immigrants are more prosaic. For example, Jyllands-Posten publisher Flemming Rose, defending his decision to run the Mohammed cartoons, referred to high immigrant crime rates. ${ }^{107}$ Likewise, a blog calling on "native" Europeans to revolt against Muslims and the European Union associated Muslims with rapes, muggings, and property damage. ${ }^{108}$ This sentiment is similar to the class-based arguments

103. See Bundesverfassungsgericht [BVerfG][Federal Constitutional Court] Sept. 24, 2003, Entscheidungen des Bundesverfassungsgerichts [BVerfGE] para. 123, 2003 (Ger.). The majority held, however, that state legislatures could ban civil servants from wearing headscarves. Id. at 282-83, 313. For an overview of the case, see Kahn, supra note 15, at 417-34.

104. For an overview of the film's contents, see Timothy Garton-Ash, Intimidation and Censorship Are No Answer to this Inflammatory Film, THE GUARDIAN, Apr. 10, 2008, http:/www.guardian.co.uk/ commentisfree/2008/apr/10/islam.religion. According to Garton Ash, the film consists of a series of film clips from terrorist acts, quotes from the Qur'an that have been used to justify violence, combined with what he calls an "alarmist" presentation of the danger Muslim migration poses to the Netherlands. Id.

105. Id.

106. See Henryk M. Broder, Geert Wilders Is No Right-Wing Populist, SPIEGEL, Apr. 1. 2008. Theo van Gogh, a Dutch comedian and filmmaker, was murdered on November 2, 2004 while bicycling in Amsterdam by Mohammed Bouyeri, a young Moroccan immigrant upset about Van Gogh's role in the making the film Submission. The film, which featured the words of the Qur'an placed on the thinly veiled body of Ayaan Hirsi Ali, was intended as a statement against domestic violence in Islam. See Jörg Victor, Theo Van Gogh Murdered on the Streets of Amsterdam, WORLD SOCIALIST WeB SiTE (Nov. 10, 2004), http://www.wsws.org/articles/2004/nov2004/gogh-n10.shtml. The murder and subsequent trial shook the nation. For two excellent book-length discussions, see RON EVERYMAN, THE assassination of Theo Van Gogh: From Social Drama to Cultural Trauma (2008); Ian Buruma, Murder IN AMSTERDAM: LibERAL EUROPE, ISLAM AND THE LiMits OF TOLERANCE (2006).

107. Rose, supra note 13. As noted above, Rose compared Danish Muslims unfavorably to Hispanics in the United States. Id. For more on Rose's arguments defending his decision to publish the cartoons, see Kahn, supra note 10.

108. Fjordman, Native Revolt: A European Declaration of Independence (May 17, 2007), http://www.islam-watch.org/Fjordman/European-Declaration-Independence.htm. 
Kulturkampf supporters made about Catholics. ${ }^{109}$ And, as in the 1870s, there is little interest in egalitarian reform; this would, to use Rose's words, be giving in to the "cult of victimology." ${ }^{110}$ Instead, the headscarf represents the wearer's socio-economic inferiority, associating her with cleaning women and fruit and vegetable vendors. ${ }^{111}$

The reference to fruit vendors leads to another similarity. Just as liberal supporters of the Kulturkampf saw Catholics as backwards and provincial-Islam's European critics view Islam as pre-modern. For example, Wilders has called the burqa "medieval." ${ }^{112}$ In an interview with the Jyllands Posten concerning the Danish cartoon affair, Ayaan Hirsi Ali informed readers that "Islam hasn't undergone all the reforms and adjustments which Christianity and Judaism have undergone over the last thousand years." ${ }^{113}$ Meanwhile, there have been calls for a Muslim "Reformation"114_an interesting request given that the Protestant Reformation was launched against the Catholic Church.

Another similarity with the Kulturkampf is the use of imagery to define the pre-modern Other. Just as Busch's Pater Filucius, a book about an avaricious Jesuit, targeted Catholics, the Jyllands-Posten's twelve cartoons offended Muslim sensibilities. Likewise, cartoons played a role in the development of anti-Semitism in the late nineteenth and early twentieth centuries, culminating in the pictures appearing in Julius Streicher's Der Stürmer. ${ }^{115}$ Given this history, one wonders what precisely Flemming Rose and the supporters of the Danish cartoons had in mind when they invited Muslims to take part in a Danish/European tradition of satire.

The United States' experience with clerical garb laws also parallels many of the concerns raised by opponents of the headscarf. As in the United States, Europeans have debated whether the headscarf states a fact

109. See supra notes 47-50 and accompanying text.

110. Rose, supra note 13.

111. This, at least, is how the debate worked out in Germany. Supporters of the hijab countered by pointing out that headscarf wearers worked in a number of modern professions-including as teachers. Kahn, supra note 15 , at 431.

112. Mardell, supra note 102.

113. The Twelve Muhammad Cartoons: A Survey of the European Press, SIGNANDSIGHT.COM (Feb. 24, 2006), http://www.signandsight.com/features/590.html (translating and reprinting a JYLLANDS POSTEN interview with Ayaan Hirsi Alifrom Feb 7, 2006).

114. Diana Muir, Op-Ed., Risks in a Muslim Reformation, WASH. Post, Aug. 19, 2007, http:// www.washingtonpost.com/wp-dyn/content/article/2007/08/17/AR2007081701691.html.

115. Because of his activities with Der Stürmer, Streicher was tried and sentenced to death at Nuremburg. For a brief overview of the prosecution, see Christopher Scott Maravilla, Hate Speech as a War Crime: Public and Direct Incitement to Genocide in International Law, 17 TUL. J. OF INT'L \& COMP. LAW 113, 117-19 (2008). 
(that the wearer is Muslim) or sends a proselytizing message. ${ }^{116}$ In fact, in the 2003 Ludin case the court appointed experts to answer this very question. ${ }^{117}$ There was also a considerable debate about the freedom of the wearer. Just as people asked whether a nun, by virtue of her vows, was a pawn of the church, opponents of the headscarf often argue that it is worn out of family pressure. ${ }^{118}$

The headscarf-like the nun's habit-is seen as a threat to the preservation of the state. Opponents worry about neutrality in both cases. Just as the Catholic nun teaching in public schools violated the U.S. constitutional understanding of church-state separation, the German teacher who wears a headscarf violates the German tradition of an independent civil service. ${ }^{119}$ And, in both cases, this neutrality was partially a pretext. As the debate in the United States over the Blaine Amendment shows, the Republican Party used separation of church and state to gain anti-Catholic votes. ${ }^{120}$ Likewise, I would argue that the concerns about civil service neutrality in Germany were only the tip of a much a larger debate about the role of Islam in society.

What accounts for the similarities between the anti-Catholic arguments made during the Kulturkampf and the current anti-Muslim arguments made in Europe today? This is a complex and under-researched question. Peter O'Brien, an expert on anti-Islamic movements, has offered one intriguing possibility: liberals are unable to deal with groups they cannot convert to their cause. ${ }^{121}$ According to O'Brien:

Muslims irk the European liberal because they refuse to convert, even after generations. They congregate in ethnic ghettos, form their own exclusive organizations. They forbid their children to attend public schools or attend Qur'an schools to unlearn what is taught in the public schools. They wear distinctive clothes. ${ }^{122}$

116. This was a major issue in the Ludin case. See Kahn, supra note 15, at 418-19.

117. Id. at 427 .

118. Pascale Fournier \& Gökçe Yurdakul, Unveiling Distribution: Muslim Women with Headscarves in France and Germany, in MigRATION, CitizenshiP AND ETHNOS 167-84 (Michal Y. Bondemann \& Gökçe Yurdakul eds., 2006).

119. Kahn, supra note 15 , at 428.

120. See supra notes 66-67 and accompanying text. This is not to say that every supporter of church-state separation was anti-Catholic or vice versa.

121. O'Brien's remarks are described in a press account of his May 2004 speech at UCLA. Leslie Evans, Is Europe Unable to Assimilate its Growing Islamic Minority?, UCLA INT'L INST. (May 26, 2004), http://www.international.ucla.edu/article.asp?parentid=11511.

122. Id. 
Nineteenth century supporters of the Kulturkampf and clerical garb laws had similar concerns about Catholics who, from their perspective, clung to their reactionary ultramontanism, pre-modern rituals and distinctive clothing. Consequently, nineteenth century, liberals on both sides of the Atlantic responded with legal restrictions. But how effective were these laws? What do those laws tell us about current laws targeting Muslims? To those questions we now turn.

\section{THE KULTURKAMPF AND CLERICAL GARB LAWS IN PRACTICE}

Acting on growing anti-Catholic sentiments, Bismarck enacted a series of restrictive laws during the 1870s. In 1871, he passed a law making it illegal to make political speeches from the pulpit. ${ }^{123}$ The following year he excluded members of religious orders from teaching in public schools. ${ }^{124}$ The May Laws of 1873 - perhaps the key measure of the Kulturkampfplaced the training and appointment of clergy in the hands of the state. ${ }^{125}$ Other laws banned the Jesuits and required civil marriage. ${ }^{126}$ By these means, Bismarck and the national liberals had hoped to create a new German Catholic - that is to say, a moderate - who would support Berlin rather than Rome.

Kulturkampf supporters had hoped for a "quick and easy victory over the church." ${ }^{127}$ Bismarck and his allies were convinced that the declaration of Papal infallibility had divided German Catholics. ${ }^{128}$ And, in fact, discontent had developed in German Catholic circles. A group of "Old Catholics" - made up of academics, civil servants, and other members of the middle class - did break away from the Church during the 1870 s. ${ }^{129}$ The Old Catholics opposed what they saw as Rome's usurpation of German political sovereignty. ${ }^{130}$ They also removed those elements of Catholic religious practice-including the Latin Mass, auricular confessions, clerical celibacy, and the cult of saints - that German liberals found problematic. ${ }^{131}$ As such, the Old Catholics looked like ideal allies in Bismarck's campaign against the Pope.

123. Ross, supra note 19 , at 6 .

124. Id.

125. Id.

126. Id.

127. Id. at 54 .

128. Id. at 35 .

129. Id. at 36-37.

130. Id. at 38 .

131. Id. at 49 . 
These hopes proved illusory. Even at their peak in the mid-1870s, the Old Catholics never made up more than one percent of the Catholic population in Germany. ${ }^{132}$ Old Catholics failed to gain greater support for two reasons. First, though the Old Catholics captured some of the elite, they lacked the support of the rank and file. The same changes in ritual that made liberals happy kept the Catholic masses away-especially at a time when the Church as a whole was under attack. ${ }^{133}$ Second, for all the German liberals' talk of modernizing Catholicism, the state's financial support for the Old Catholics was lukewarm at best. ${ }^{134}$ Behind this apparent support was a continuing atmosphere of hostility toward Catholicismincluding Old Catholics. ${ }^{135}$

More generally, Bismarck and his allies underestimated the will of the Catholics to resist. When the May Laws were passed, the district governor of Trier thought that "jailing a few priests" would be enough to ensure compliance with the registration requirement. ${ }^{136}$ Instead massive resistance ensued, ${ }^{137}$ as well as clever schemes to get around the full force of the law. For instance, to prevent the state from confiscating church property of clergy who resisted registration, lay Catholics would purchase the property at a low price and then let the clergy member in question reside there. ${ }^{138}$

By 1874, that the May Laws had failed was obvious. In a speech before Parliament, Bismarck demanded to know whether "the state [could] tolerate the continuous mocking of its laws" and called for more stringent legislation, which resulted in the 1875 Expulsion Law that subjected recalcitrant clergy to exile. ${ }^{139}$ However, as time went on and the resistance continued, German Catholics lost respect not only for the Kulturkampf but for the authority of law itself. ${ }^{140}$ Meanwhile, in the eastern provinces with large concentrations of Poles, authorities turned a blind eye to the Catholic

132. See id. at 41 .

133. Id. at 49 .

134. Id. at 43 .

135. Id. at 41. As one anti-Catholic critic put it: "Before the infallibility the Catholics at the command of the pope believed that twice two were seven; now, however, when he wishes them to believe that twice four are nine [the Old Catholics] refuse to do so." Id. (quoting Entry by Gregorovious on Apr. 7, 1872, in The Roman Journals of FERDinAND GREGOROVIOUS 428 (Friedrich Althaus ed., Gustavus W. Hamilton trans., George Bell \& Sons 1907)).

136. Id. at 54 .

137. Id. at 61. By the end of the Kulturkampf, authorities in Trier had assessed 80,925 marks in fines and ordered clergy to serve 11,975 days in jail. Id.

138. Id. at 57 .

139. Id. at 69-70.

140. Id. at 122 . 
resistance lest the end of ecclesiastical authority result in a general breakdown of law and order. ${ }^{141}$

The Catholic resistance was aided by some unintended consequences of Bismarck's laws. Although Bismarck wanted to censor the Catholic newspapers, he needed them to carry his pronouncements. ${ }^{142}$ Likewise, the 1874 law establishing compulsory civil marriage took pressure off the beleaguered Catholic clergy, which, because of the May Laws, was rapidly dwindling in numbers. ${ }^{143}$ The Kulturkampf also had partisan repercussions. Much to Bismarck's despair, the Catholic Center Party grew noticeably during the $1870 \mathrm{ss}^{144}$ The development of a powerful, assertive Catholic political party further weakened support for the Kulturkampf. ${ }^{145}$

Although diplomatic negotiations between Berlin, Rome, and German Catholics lingered into the 1880s, the period of active repression was over by 1878 . There were several external reasons for this including the death of Pius IX and a political alliance between the German Empire and Catholic Austria-Hungary - thus ending Germany's fear of being encircled by hostile Catholic powers. ${ }^{146}$ But equally important were conservative Protestant protests, the growing strength of the Center Party, and a general sense of exhaustion. ${ }^{147}$ Meanwhile, if the goal of the Kulturkampf was the isolation of German Catholics, it failed. Writing in 1908, the author of one Catholic Encyclopedia entry concluded that "[o]ne important consequence of the Kulturkampf was the earnest endeavor of the Catholics to obtain a greater influence in national and municipal affairs; how weak they were in both respects was clear to them only after the great conflict had begun." 148

The experiences in the United States with clerical garb laws followed a similar pattern. As we have seen, many states passed such laws in the late nineteenth century. ${ }^{149}$ When it came time, however, to use the laws, American opponents of Catholics encountered the same problems as their German counterparts.

141. Id. at 150 .

142. Id. at 122 .

143. Spahn, supra note 39, at 708. According to Spahn, but for the civil marriage law, "the Catholic population ... given the absolute necessity of marriages, would have had to . . . either tolerate the state clergy or . . . bring pressure to bear on the Catholic clergy" to obey the new laws. Id.

144. Ross, supra note 19, at 123-25.

145. Id.

146. Spahn, supra note 39, at 709 .

147. Id. See also Ross, supra note 19, at 68-69.

148. Spahn, supra note 39 , at 710.

149. See supra note 73 and accompanying text. 
A good example of the these difficulties can be seen in Hysong $v$. Gallitzin Borough School District, a case involving the town of Gallitzin, population 3,000, which was roughly eighty percent Catholic. ${ }^{150}$ Several nuns were employed as teachers at the public school. ${ }^{151}$ Protestant students and parents sued, arguing that this practice violated Article 10 of the Pennsylvania Constitution, which - in the spirit of the Blaine Amendment - made it illegal to spend public money in support of "any sectarian school."152

According to the Protestant plaintiffs, the nuns wore their "garb, insignia, and emblems ... in such a manner as to impart to the children under their instruction certain religious and sectarian lessons[.]" ${ }^{153}$ The plaintiffs also expressed concern that the nuns, by renouncing their worldly names, subjected themselves to church discipline. The plaintiffs also alleged that the nuns were unable to converse with males over fourteen years old-which, they claimed, would prevent the teaching of hygiene. ${ }^{154}$ There were also allegations that the nuns taught the Catechism during school hours and received visits from local priests. ${ }^{155}$ In its defense, the Church denied teaching the Catechism during school hours and said that nothing in the church rules prohibited nuns from conversing with members of the opposite sex or teaching hygiene. ${ }^{156}$

At the trial thirty-seven witnesses testified about a wide variety of issues, including the meaning of the nun's oath of poverty and the nature of the requirement that nuns wear the habit. The nuns were not allowed to take off the habit either "on account of their work" or "because of the heat of the day." 157 The Pennsylvania trial court sided with the defendants on the issue of teaching physical hygiene - there was simply no evidence that they could not teach the subject. ${ }^{158}$ Reviewing the case law, the court also found support for the idea that schools should not become "the medium for disseminating [religious] beliefs" but concluded that the school board's hiring of nuns, however unwise, would have to stand given the absence of

150. The material in this and the next paragraph comes from the lower court opinion in Hysong which is appended to the Supreme Court opinion in the LEXIS version of the case. Hysong v. Gallitzin Borough School District, No. 295, 1894 Pa. LEXIS 1133, at*17 (Pa. Super. Ct. 1894).

151. See id. at*1.

152. Id. at *7.

153. Id. at $* 2$.

154. Id.

155. Id. at $* 3, * 16$.

156. Id. at $* 8-9$.

157. Id. at $* 18$.

158. Id. 
any law explicitly banning the wearing of clerical garb. ${ }^{159}$ The court then helpfully pointed out that other states had much stricter laws. ${ }^{160}$

The Pennsylvania Supreme Court affirmed, in an opinion that was much more critical of the plaintiff's position. ${ }^{161}$ The Court noted that other religious groups - such as the Quakers - wore distinctive garb and asked whether courts were to decide whether "the cut of a man's coat" or "the color of a woman's gown" are evidence of "sectarian" teaching. ${ }^{162}$ There was, however, a vigorous dissent. By renouncing the world, nuns have "ceased to be civilians or secular persons." ${ }^{163}$ Although "taste or fashion in dress" should be favored by the "largest liberty," the clerical robes mark nuns off as "representatives of a particular order in a particular church whose lives have been dedicated to religious work under the direction of that church." 164 This, claimed the dissent, was how the Protestant children of Gallitzin, Pennsylvania saw the nuns. ${ }^{165}$

The following year, the Pennsylvania legislature responded by enacting a clerical garb law that had the goal of avoiding "all appearances of sectarianism ... in the administration of the public schools[.]"166 Though the Pennsylvania law was upheld, ${ }^{167}$ the overall record of clerical garb laws has been mixed - with courts in North Dakota and Indiana striking down such laws on the basis that they were mere pretexts for anti-Catholic bias. ${ }^{168}$ On the other hand, the New Mexico Supreme Court upheld a state school board resolution banning clerical garb, ${ }^{169}$ and in 1986 the Oregon Supreme Court upheld that state's clerical garb law. ${ }^{170}$

159. Id. at $* 24, * 31$.

160. Id. at $* 33$.

161. Id. at $* 58$.

162. Id. at $* 55$.

163. Id. at $* 59$ (Williams, J., dissenting).

164. Id. at $* 62$.

165. Id. at *61-64.

166. Commonwealth v. Herr, 39 Pa. Super. 454, 468 (1910) (characterizing the legislature's goal in enacting the statute regarding religious garb, which the Pennsylvania Supreme Court proceeded to uphold).

167. Id.

168. See Blum, supra note 20 , at $875-76$.

169. Zellers v. Huff, 236 P.2d 949, 968-69 (N.M. 1951).

170. Cooper v. Eugene Sch. Dist., 732 P.2d 298, 314 (Ore. 1986). In upholding Ore.Rev.Stat. §§ 342.650 in a case involving a Sikh, the Oregon Supreme Court stressed that the obligation of a teacher to adhere to religious neutrality was not limited to members of the majority religion. It then added that — while the plaintiff's dress may seem like "an exotic curiosity" — one must also keep in mind that, given "[t]he tides of immigration and home grown religions," what the court finds "exotic today may tomorrow gain many thousands of adherents and potential majority status in some communities." In reaching this conclusion, the court mentioned the Know-Nothing movement of the mid-nineteenth century and the Blaine Amendment—both expressions of anti-Catholic nativism. Oddly enough, it saw 
More recently, however, the trend has gone against clerical garb laws. Pennsylvania's clerical garb statute has been called into question as possibly violating the Establishment Clause because of its tendency to endorse a specific religious view. ${ }^{171}$ Oregon's clerical garb law was repealed in $2010 .^{172}$

One difficulty posed by clerical garb laws is determining whether the clothing in question is religious. Although this is relatively easy with the nun's habit, it is proven more difficult for other types of head covering, as exemplified in EEOC v. Reads, Inc. ${ }^{173}$ In Reads, an auxiliary teacher, Cynthia Moore, was dismissed for wearing a colored scarf on her head. ${ }^{174}$ In ruling for Moore, the court noted that the company had presented no evidence that she wore the scarf for religious reasons. ${ }^{175}$ The court also noted that Moore and her Imam had made statements that the headscarf had no religious significance. ${ }^{176}$ This last evidence made the court a bit uneasy; while crediting the statements of Moore and the Imam, it explained that it had no wish to "rule on matters of compliance with the requirements of a particular religion."177

The Mississippi Supreme Court did not have such qualms in a slightly different case, Mississippi Employment Security Commission v. McGlothin. ${ }^{178}$ Deborah McGlothin, a teacher, sought unemployment benefits after she was dismissed from her job as a school teacher in response to her wearing a religious head covering. ${ }^{179}$ The Mississippi Employment Security Commission argued that the head covering was an expression of McGlothin's Ethiopian cultural background-and that therefore she was not dismissed from her job because of her religion and

these events as a reason to support the law, since they showed how easily religious beliefs could give rise to the type of "contention" that imperils religious neutrality.

171. See Nichol v. Arin Intermediate Unit 28, 268 F. Supp. 536, 550 (W.D. Pa. 2003).

172. See Betsy Hammond, Governor Signs Repeal on Teachers' Religious Dress; Ban Will Lift in July 2011, OREGONLIVE.COM (Apr. 1, 2010, 1:25 PM) http://www.oregonlive.com/education/ index.ssf/2010/04/governor_signs_repeal_on_teach.html (noting that the effort for repeal was lead by a broad coalition of interfaith and civil rights groups but was opposed by the Oregon ACLU, which warned that repeal risked endangering the "religious neutrality" of public schools); see also Coalition Seeks Repeal of Klan-era Ban on Religious Garb in Oregon Schools, CATHOLIC NEWS AGENCY (Feb. 7 , 2010), http://www.catholicnewsagency.com/news/coalition_seeks_repeal_of_klan-era_ban_on _religious_garb_in_oregon_schools/\#.

173. 759 F.Supp. 1150,1158 (E.D. Pa. 1991).

174. Id. at 1153-54.

175. Id. at 1158 .

176. Id.

177. Id. at 1158 n. 11 .

178. 556 So.2d 324 (Miss. 1990).

179. Id. at 327 . 
was not entitled to benefits. ${ }^{180}$ In rejecting this argument, the court held that McGlothin was dismissed on religious grounds even though: (1) the Hebrew Israelite group to which she belonged did not require that women wear headdresses; (2) she did not regularly attend church services; and (3) she was "selective" in wearing the head covering. ${ }^{181}$ In reaching this conclusion, the court noted that "millions of women (and some men) around the world cover their head as a matter of religious and cultural custom" and that "many religious practices have a cultural component." ${ }^{182}$

Although the history of the enforcement of clerical garb laws in the United States may lack the drama of the Kulturkampf, two themes emerge: (1) given the prevalence of religious clothing across a large number of faiths, laws that single out the clothing of Catholics (or Muslims) are increasingly likely to be seen as discriminatory; and (2) because people wear clothing for a wide variety of reasons, courts encounter great difficulty in determining whether a given item is, in fact, worn for religious reasons.

\section{FOUR SPECULATIVE CONCLUSIONS ABOUT TODAY'S ANTI- HEADSCARF LAWS}

What then do the experiences of Germany and the United States in restricting public expressions of Catholicism suggest about Europe's antiheadscarf laws? Here are four speculative conclusion.

First, the headscarf and burqa bans will most likely not achieve the goal of "integrating" European Muslims, especially if one defines "integration" as separating "moderate" Muslims from their more extremist counterparts. Just as the imposition of the Kulturkampf made the Catholic rank-and-file less receptive to the Old Catholics' message, it is hard to see how banning the headscarf will win over ordinary Muslims. Bans will instead increase the likelihood that those women who continue to wear the headscarf (or burqa) will learn to see it not only as a religious duty but also as a symbol of resistance to secular Western society. ${ }^{183}$ More generally, the experience of the Kulturkampf suggests that measures aimed to suppress or

180. Id.

181. Id. at 330 .

182. Id. at 330-31. Interestingly, in holding for McGlothin, the court rejected an argument from the school board that her headscarf interfered with the teaching of health and hygiene - an argument that recalls earlier objections to nuns teaching hygiene, as well as some current objections to the hijab.

183. See Raphaël Liogier, France's Attack on the Veil Is a Huge Blunder, THE GuARdian (Jan. 26, 2010), http://www.guardian.co.uk (arguing against the French burqa ban by asserting that those women who, to avoid the burqa ban, stay at home will become more dependent on their families, more desperate, and ironically better targets for Islamist recruitment). 
"regulate" a religious minority will in the end spur it to greater political mobilization - this at least was what happened with the rise of the Center Party and the determination of German Catholics to never again put themselves in a position where they could not respond to legal repression. $^{184}$

Second, the bans will be hard to enforce. As a practical matter, bans on religious behavior are very difficult to enforce. Religious practices, like wearing the headscarf, are part of daily life, even if, as in the case of Deborah McGlothin, they are incorporated selectively. As a result, restrictions encounter deep resistance. A comparison to the hate speech context is instructive. A ban on hate speech works politically because, in general, no one in society claims to be in favor of hate. As a result, the laws - even if they are ineffective - are not likely to antagonize any group in society. ${ }^{185}$

By contrast, when Europeans ban the burqa or headscarf because it is a sign of "political Islam," "totalitarianism," or "extremism"—in the manner of the Kulturkampf in Germany and anti-Catholic hysteria in the United States - they insult Muslims even before the laws are enforced. Oddly for secular liberals, who generally seek to separate what one does in private with what one does in public, ${ }^{186}$ there is a great desire to unpack the meaning of the headscarf. Wouldn't it be more consistent with the liberal separation of public and private to ban the specific bad things the headscarf is said to represent-honor killing and terrorism, for example-rather than to ban a clothing item many women wear for completely unrelated reasons?

Third, banning religious clothing from one faith raises questions about whether garments of other faiths should be banned as well. The Pennsylvania Supreme Court in Hysong was troubled because Protestants, as well as Catholics, wore religious clothing. ${ }^{187}$ Likewise, the Federal Constitutional Court ruling in Ludin left it unclear whether German states

184. See Ross, supra note 19 and accompanying text.

185. See Mari J. Matusda, Public Response to Racist Speech: Considering the Victim's Story, 87 MicH. L. REV. 2320, 2338 (1989) ("To be hated, despised, and alone is the ultimate fear of all human beings.") (emphasis added). For an insightful discussion of the historical development of hate speech bans, see Cyril Levitt, Introduction to UNDER THE SHADOW OF WEIMAR: DEMOCRACY, LAW, AND INCITEMENT IN SIX COUNTRIES, 3-15 (Louis Greenspan \& Cyril Levitt eds., 1993) (describing how many European democracies enacted hate speech laws in the 1960s and 70s).

186. See Jeff Weinraub, The Theory and Politics of the Public/Private Distinction, in PUBLIC AND Private in Thought And PRActice: Perspectives on A Grand Dichotomy (Jeff Alan Weinraub \& Krishan Kumar eds., 1997). For a classic critique, see Duncan Kennedy, The Stages of Decline of the Public/Private Distinction, 130 U. PA. L. REV. 1349 (1982).

187. Hysong v. Gallitzin Borough Sch. Dist., 30 A. 482 (Pa. 1894). 
that had banned the headscarf would also be required to ban the crucifix. ${ }^{188}$ The stakes in this debate are high. Banning the headscarf alone raises questions of religious discrimination; banning the headscarf and crucifix (and other religious symbols) risks pushing society in an overly secular direction. These questions are not merely academic. When, in the wake of the Ludin case, the then president of the Federal Republic of Germany, Johannes Rau, suggested that any ban on headscarves should also apply to "a monk's habit or a crucifix," he was met with sharp criticism. ${ }^{189}$

Fourth, because a headscarf can mean different things to different people, courts and legislatures will have to decide whether to focus on the wearer's motives, the impact on the audience (school children in the case of teachers), or the message sent to the larger society by wearing a headscarf. As Reads and McGlothin show, these are not easy questions. Should the ban apply where the garment is worn selectively or for non-religious reasons by someone who is unaffiliated with a religious group? Should the ban apply to someone who, though religious in other respects, wears the garment as a "fashion statement"? And how can a court-or anyone elsedetermine whether school children interpret a headscarf as a statement of the fact their teacher is Muslim, as opposed to an effort to convert them to Islam? Given the large number of Muslim women who wear the headscarf in public, these questions are unlikely to go away anytime soon. ${ }^{190}$

\section{CONCLUSION: LOOKING TOWARDS THE FUTURE}

Despite these practical difficulties, the current trend in European politics favors bans on Islamic clothing. ${ }^{191}$ The bans draw support from a view that such clothing is, to use the words of French President Nicolas Sarkozy, "contrary to our values and contrary to the ideals we have of a woman's dignity." 192 As we have seen, in the late nineteenth century, similar concerns were raised about the nun's habit in the United States. ${ }^{193}$

Today, however, concerns about the nun's habit, if expressed at all, are much fainter. Instead, at a time when bans on Islamic clothing are on the

188. See Kahn, supra note 15 , at 429.

189. Id. at $430 \mathrm{n} .111$ (internal citations omitted).

190. In future work I want to show more direct parallels between the anti-Catholic laws of the nineteenth century and the current laws targeting Muslims. One interesting overlap involves citizenship. Just as Germany and Denmark today are requiring Muslims to take citizenship tests, the May Laws of 1873 required clergy to pass examinations in philosophy and related subjects. See Ross, supra note 19, at 54-55.

191. See Erlanger, supra note 1.

192. Id. (quoting Sarkozy).

193. See supra notes 73-76 and accompanying text. 
rise in Europe and elsewhere, anti-Catholic laws are notable for their obscurity. Viewed from the vantage point of the twenty-first century, the anti-Catholicism of the Kulturkampf and clerical garb laws looks antiquated. Although pockets of anti-Catholicism persist in the United States and in Europe, the general picture has changed remarkably. The current government of the Federal Republic of Germany is led by the Christian Democrats, a successor to the German Center Party that combines Protestants and Catholics and, as such, symbolizes the acceptance of Catholics into German society. ${ }^{194}$

Likewise, John F. Kennedy's election as president in 1960 showed the extent to which Catholics had become an accepted part of American social and political life. Writing on the occasion of Kennedy's funeral, E. Digby Baltzell noted how much had changed over the past 50 years. Explaining how "hope and faith rank higher than confidence in the hierarchy of human virtues," Baltzell continued:

Theodore Roosevelt was a dreamer of dreams who dared to hope that America would, in the long run, conquer the values of caste and someday send a distinguished Catholic, and eventually a Jew, to the White House. Among other things, this funeral dramatized the fact that part of his hopes have now been realized. ${ }^{195}$

Hope is not a stranger to Europe. One day, European Muslims will be as "integrated" into their society as U.S. and German Catholics are today. The path will not necessarily be an easy one, but when that time is reached, hopefully headscarf laws will be as passé as the Kulturkampf and clerical garb laws are today.

194. See Merkel Becomes German Chancellor, BBC NEWS (Nov. 22, 2005), http://news.bbc.co.uk/ 2/hi/europe/4458430.stm. For a discussion of the origins of the CDU, see NOEL D. CARY, THE PATH TO Christian Democracy: German CATHOlics AND THE PARTY SySTEM FROM Windthorst to ADENAUER, viii-x (1996).

195. BALTZELL, supra note 64 , at $\mathrm{XV}$. 